\title{
Implikasi Pengujian Ketetapan MPR dalam Sistem Ketatanegaraan Republik Indonesia Pasca Putusan Mahkamah Konstitusi No. 75/PUU-XII/2014
}

\author{
Tomi Agustian \\ Universitas Islam Indonesia Yogyakarta \\ Jl. Cik Ditiro, Yogyakarta. \\ tomi_agustian@yahoo.co.id
}

\begin{abstract}
This research studies the problems about: first, the base of Constitutional Court (MK) does not accept any application of judicial review of MPR (provisional people's consultative assembly), second, the implication of the trial of MPR provisions in post-verdict of Constitutional Court. This research is a normative research that obtained primary legal materials in the form of the Verdict of Constitutional Court and supported with books, articles and documents. The results of the research concluded that first; the Constitutional Court in accordance with the Constitution 1945 Article 24C Sentence (1) does not have any authority to test the provision of MPRS. Second, the implication of the verdict of Constitutional Court does not cause the absence of mechanism of the trial of the MPR's provisions; thus causing the legal vacuum and the absence of the institution that is authorized to do a trial towards the MPR's provisions (tetraa incognita).
\end{abstract}

Keywords: Implication, trial, provision of MPR, verdict of constitutional court

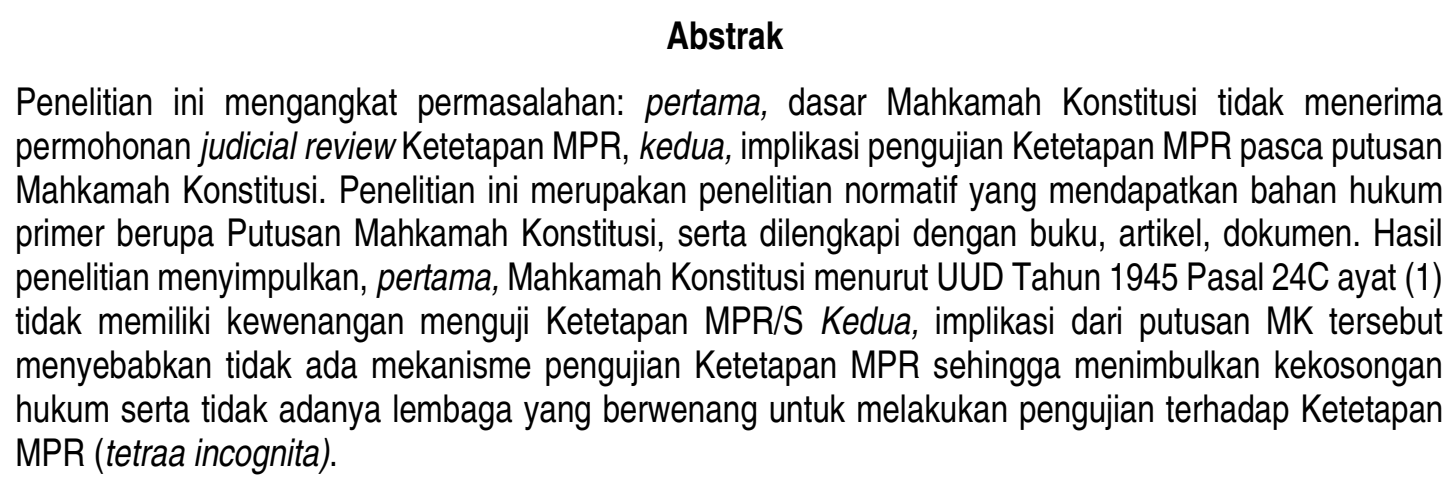

Kata Kunci: Implikasi, pengujian, ketetapan MPR, putusan MK. 


\section{Imx Renaissance No. 1 VOL. 1 JANUARI 2016: 1 - 16}

\section{Pendahuluan}

Perubahan Undang Undang Dasar Negara Republik Indonesia Tahun 1945 Pasal 1 ayat (2), menyebutkan bahwa kedaulatan berada di tangan rakyat dan dilaksanakan menurut Undang Undang Dasar. Ketentuan pada Pasal 1 ayat (2) ini selanjutnya dipertegas oleh Pasal 1 ayat (3) yang menyatakan bahwa negara Indonesia adalah negara hukum.

Ketentuan konstitusional tersebut berarti bahwa sistem ketatanegaraan Indonesia berdasarkan Undang Undang Dasar 1945 harus berdasarkan atas prinsip kedaulatan rakyat dan prinsip negara hukum. Artinya, dari sudut pandang konstitusional berdasarkan ketentuan Pasal 1 ayat (2), dan Pasal 1 ayat (3) UUD 1945, maka segala bentuk keputusan dan tindakan aparatur penyelenggara pemerintahan negara harus berdasarkan atas prinsip kedaulatan rakyat dan hukum, dan tidak berdasarkan kekuasaan yang melekat pada kedudukan aparatur penyelenggara pemerintahan itu sendiri. ${ }^{1}$ Pada Undang Undang Dasar 1945 hasil amandemen, Majelis Pemusyaratan Rakyat tidak lagi berada pada posisi lembaga tertinggi negara, tetapi berubah menjadi lembaga tinggi negara sederajat dengan lembaga negara lainnya.

Ditempatkannya kembali Ketetapan MPRS dan Ketetapan MPR RI sebagai salah satu jenis perundang-undangan dalam hierarki perundang-undangan sebagaimana diatur dalam Pasal 7 ayat (1) huruf b, Undang-Undang Nomor 12 Tahun 2011 tentang Pembentukan Peraturan Perundang-undangan didasarkan pada pemikiran dari kelemahan-kelemahan yang terkandung dalam UU Nomor 10 Tahun 2004 tentang Pembentukan Peraturan Perundang-undangan. Salah satu penyempurnaan tersebut adalah penambahan Ketetapan MPR/S sebagai salah satu jenis peraturan perundang-undangan yang ditempatkan setelah UUD NRI 1945. Ketetapan MPRS/MPR yang dinyatakan masih berlaku sesuai Ketetapan MPR Nomor I/MPR/2003 dan sesuai pula dengan Undang-undang Nomor 12 Tahun $2011 .^{2}$

Berbagai pendapat para ahli hukum tata negara yang membahas Ketetapan Majelis Pemusyawaratan Rakyat dapat dilakukan pengujian ke Mahkamah Konstitusi, karena Mahkamah Konstitusi yang lebih berwenang menguji Ketetapan MPR tersebut, menurut peneliti tentu saja hal ini akan bertentangan dengan Undang Undang Dasar 1945.

Mahkamah Konstitusi tentu diragukan kewenangannya untuk menguji Ketetapan MPR bila dilihat dari kedudukan TAP MPR dalam hierarki perundang-undangan. ${ }^{3}$

\footnotetext{
hlm. 26 .

${ }^{1}$ Dahlan Thaib, Ketatanegeraan Indonesia Persfektif Konstitusional, Penerbit Total Media, Yogyakarta, 2009,

${ }^{2}$ Titik Triwulan Tutik. "Analisis Kedudukan dan Status Hukum Ketetapan MPR RI berdasarkan UndangUndang Nomor 12 Tahun 2011 Tentang Pembentukan Peraturan Perundang-Undangan”. Artikel dalam Jurnal Hukum Ius Quia Iustum, Vol. 20 No. 1, Januari 2013, hlm. 3.

${ }^{3}$ Lihat, UU Nomor 12 Tahun 2011 Pasal 7 ayat (1) huruf b.
} 
Sebagaimana diketahui bahwa TAP MPR telah diajukan permohonan judicial review beberapa kali ke Mahkamah Konstitusi, tetapi permohonan para pemohon dianggap kabur dan tidak dapat diterima oleh sidang Majelis Mahkamah Konstitusi. Contoh yang pertama, atas Putusan Mahkamah Konstitusi Nomor 86/PUU-XI/2013 tentang Pengujian UU Nomor 12 Tahun 2011. Dalam materi yang diujikan Pasal 7 ayat (1) hurup b ditempatkan TAP MPR dalam susunan hierarki perundang-undangan dan tidak ada lembaga negara yang berwenang mengujinya, sehingga menimbulkan ketidakpastian hukum pengujian TAP MPR ini, dan Mahkamah Konstitusi mengadili dan dan memutuskan tidak menerima permohonan yang diajukan oleh Viktor dan kawan-kawan. ${ }^{4}$ Putusan yang kedua, Nomor 75/PUU- XII/2014 tentang Pengujian Ketetapan MPR No. I/MPR/2013 tentang Peninjauan Terhadap Materi dan Status Hukum TAP MPR 1960 sampai 2002 terhadap Undang Undang Dasar NRI 1945, dengan materi yang diujikan Pasal 6 angka (30) Pengujian TAP MPRS No. XXXIII/MPRS/1967 tentang pencabutan kekuasan pemerintahan dari Presiden Soekarno. ${ }^{5}$ Mahkamah Konstitusi mengadili dan tidak menerima permohonan yang diajukan oleh Murnanda Utama dan kawan-kawan dari Yayasan Maharya Pati, karena permohonan pemohon dianggap kabur dan pengujian mengenai Tap MPR Nomor I/MPR/2003 tentang Peninjauan Terhadap Materi dan Status Hukum Tap MPR 1960 sampai 2002 terhadap Undang Undang Dasar NRI 1945, dengan materi yang diujikan Pasal 6 angka (30) Pengujian Tap MPRS No. XXXIII/MPRS/1967 tentang pencabutan kekuasan pemerintahan dari Presiden Soekarno ini, adalah yang kedua kalinya dilakukan permohonan pengujian ke Mahkamah Konstitusi. Sebelumnya pernah diajukan judicial review oleh Rahmawati Soekarno Putri - putri dari mantan Presiden Ir. Soekarno bersama Yayasan Universitas Bung Karno dengan risalah Sidang Nomor 24/PUU-XI/2013 dengan Putusan yang sama yaitu Mahkamah Konstitusi mengadili dan tidak menerima permohonan tersebut. ${ }^{6}$

\section{Rumusan Masalah}

Berdasarkan latar belakang masalah yang telah diuraikan tersebut, maka permasalahan dalam penelitian ini adalah: pertama, apakah yang menjadi dasar hukum Mahkamah Konstitusi mengadili dan tidak menerima judicial review Ketetapan MPR? Kedua, apa implikasi Putusan Mahkamah Konstitusi tersebut terhadap pengujian Ketetapan MPR?

\footnotetext{
${ }^{4}$ Putusan Mahkamah Konstitusi Nomor 86/PUU-XI/2013.

${ }^{5}$ Putusan Mahkamah Konstitusi Nomor 75/MPRS/2014.

${ }^{6}$ Risalah Sidang Perkara Nomor 24/PUU-XI/2013.
} 


\section{IFx Renaissance No. 1 VOL. 1 JANUARI 2016: 1 - 16}

\section{Tujuan Penelitian}

Adapun tujuan penelitian ini adalah: pertama, untuk mengetahui dasar putusan Mahkamah Konstitusi mengadili dan tidak menerima permohonan judicial review Ketetapan MPR. Kedua, untuk mengetahui dan menganalisis implikasi putusan Mahkamah Konstitusi terhadap pengujian Ketetapan MPR.

\section{Metode Penelitian}

Metode yang digunakan dalam penelitian ini adalah penelitian normatif atau penelitian kepustakaan, yang dilakukan untuk mendapatkan data primer dan sekunder dengan bahan penelitian berupa dokumen, buku, artikel, hasil penelitian, dan perundangundangan, seta pendapat ahli.

Pendekatan penelitian ini berupa pendekatan normatif (legal research) yakni, pendekatan perundang-undangan dan pendekatan kasus karena meneliti ratio decidendi Putusan Mahkamah Konstitusi yang ada kaitannya dengan penelitian. Pendekatan ini akan menguraikan substansi yuridis keberadaan dan kedudukan Tap MPR dalam UndangUndang Nomor 12 Tahun 2011 serta kewenangan Mahkamah Konstitusi dalam UUD 1945 termasuk beberapa menganilisis produk hukum MPR yang masih berlaku sampai saat ini. Pendekatan Kasus (case approach) digunakan untuk menganalis putusan Mahkamah Konstitusi mengenai dasar Mahakamah Konstitusi mengadili dan tidak menerima permohonan judicial review Ketatapan MPR. Pengelolaan dan penyajian Data Penelitian atau Bahan Hukum Pengumpulan data dalam penelitian ini dilakukan melalui teknik studi literatur, yang ditujukan untuk memperoleh bahan-bahan dan informasi-informasi sekunder yang diperlukan dan relevan dengan penelitian, yang bersumber dari buku-buku, dokumen, media pemberitaan, jurnal, serta sumber-sumber informasi lainnya seperti data yang terdokumentasikan melalui situs internet yang relevan.

\section{Hasil Penelitian dan Pembahasan}

Perubahan UUD 1945 melahirkan bangunan kelembagaan negara yang satu sama lain dalam posisi setara dengan saling melakukan checks and balances dalam mewujudkan supremasi hukum dan keadilan serta menjamin dan melindungi hak asasi manusia. Kesetaraan dan kesediaan saling kontrol inilah prinsip dari sebuah negara demokrasi dan 
negara hukum. ${ }^{7}$ Implikasi perubahan UUD 1945 membawa dampak yang sangat luas terhadap semua lembaga negara. Pada satu sisi, ada lembaga yang mendapat proporsi baru dengan bartambahnya wewenang secara signifikan di dalam konstitusi. Sementara di sisi lain, ada pula lembaga negara yang mengalami pengurangan kewenangannya dibandingkan sebelum dilakukan perubahan. ${ }^{8}$ Tidak hanya itu ada juga lembaga yang hilang kewenangannya karena sudah tidak relevan lagi bagi kebutuhan penyelenggaraan negara ke depan. Di antara implikasi perubahan UUD 1945, yang paling tampak perubahan kewenangannya adalah perubahan kedudukan dan fungsi Majelis Permusyawaratan Rakyat (MPR). ${ }^{9}$

Sebelum perubahan UUD NRI 1945, Indonesia menganut prinsip supremasi Majelis Permusyawaratan Rakyat sebagai salah satu bentuk varian sistem supremasi parlemen yang dikenal dunia. Oleh karena itu, paham kedaulatan rakyat yang dianut diorganisasikan melalui pelembagaan Majelis Permusyawaratan Rakyat yang dikonstruksikan sebagai lembaga penjelmaan seluruh rakyat Indonesia yang berdaulat, yang disalurkan melalui prosedur perwakilan politik (political representation) melalui Dewan Perwakilan Rakyat, Perwakilan Daerah (regional representation) melalui dewan utusan daerah, dan perwakilan fungsional (functional representation) melalui utusan golongan. Ketiganya dimaksudkan untuk menjamin agar kepentingan seluruh rakyat yang berdaulat benar-benar tercermin dalam keanggotaan Majelis Permusyawaratan Rakyat sehingga lembaga yang mempunyai kedudukan tinggi tersebut sah disebut sebagai penjelmaan seluruh rakyat. ${ }^{10}$

Dari sudut pandang yuridis ketatanegaraan pasca perubahan sistem MPR ke sistem trikameral yang terdiri dari lembaga DPR dan DPD telah memposisikan MPR bukan lagi sebagai lembaga tertinggi negara dan pelaksana sepenuhnya kedaulatan rakyat. ${ }^{11}$

Perubahan UUD 1945 memposisikan MPR tidak berkedudukan sebagai lembaga tertinggi negara dan pemegang kedaulatan rakyat tertinggi. ${ }^{12}$ Hal ini berimplikasi terhadap kewenangan MPR yang dahulu memiliki kewenangan strategis, yaitu menetapkan UUD 1945, menetapkan GBHN, memilih presiden dan wakil presiden. Setelah amademen menjadi (1) mengubah dan menetapkan UUD; (2) melantik presiden dan wakil presiden; (3) memberhentikan presiden dan wakil presiden dalam masa jabatannya menurut UUD 1945.

\footnotetext{
${ }^{7}$ Martha Pigome, "Implementasi Prinsip Demokrasi Nomokrasi Dalam Struktur Ketatanegaraan Pasca Amandemen UUD 1945” Artikel dalam Jurnal Dinamika Hukum, Vol. 113, (2000), hlm. 113.

${ }^{8}$ Kuntana Magnar, "Kedudukan, Tugas, fungsi dan Kewenangan Lembaga-Lembaga Negara Indonesia". Artikel dalam Jurnal Ilmu bukum Litigasi, Vol 1. No. 2 Th, 2007, hlm. 25.

${ }^{9}$ R. Agung Laksono, "Dewan Perwakilan Rakyat Repoblik Indonesia Pasca Perubahan Undang Undang Dasar Negara Republik Indonesia tahun 1945”, Artikel dalam Jurnal Majelis, Vol. 1 No. 1, 2009, hlm. 48.

${ }^{10}$ Sri Soemantri, Prosedur dan Sistem Perubahan Konstitusi, Penerbit P.T. Alumni, Bandung, 2006, hlm. 145. 168.

${ }^{11} \mathrm{Jimly}$ Asshiddiqie, Konstitusi dan Konstitusionalisme Indonesia, Penerbit Konstitusi Press, Jakarta, 2005, hlm.

12 Titik Triwulan Tutik, Kontruksi Hukum Tata ... Op. cit., hlm. 7.
} 


\section{Ifx Renaissance No. 1 VOL. 1 JANUARI 2016: 1 - 16}

Akibat dari ketentuan UUD NRI 1945, keberadaan MPR dalam sistem ketatanegaraan menjadi 'tawar dan mandul', termasuk produk hukum yang dihasilkan seperti Ketetapan MPR. Bahkan melalui Undang-Undang No. 10 Tahun 2004 tentang Pembentukan Peraturan Perundang-undangan, telah mencabut produk hukum MPR yang berupa Ketetapan MPR (Tap MPR) dari hirarki peraturan perundang-undangan, karena MPR tidak berwenang lagi menetapkan GBHN. Kenyataan demikian semakin memarginalkan kedudukan dan status hukum dari Ketetapan MPR, padahal berdasarkan Aturan Tambahan Pasal 1 UUD 1945 setelah amandemen menugaskan kepada MPR meninjau kembali status hukum Ketetapan MPRS/MPR guna upaya menghindari ketidakpastian status Hukum Tap MPRS/MPR.

\section{Ketetapan MPR Nomor I/MPR/2003 tentang Peninjauan Materi Status Ketetapan MPR dari Tahun 1966 sampai dengan 2002}

Sesuai dengan ketentuan hasil perubahan UUD 1945 sebagaimana digariskan Pasal 1 Aturan Tambahan yang memberikan tugas kepada MPR untuk melakukan peninjauan terhadap materi dan status hukum Ketetapan-ketetapan MPRS dan MPR (legislative review). ${ }^{13}$ Selanjutnya, forum musyawarah sidang-sidang MPR periode 1999-2004 menghasilkan Ketetapan MPR No. 1/MPR/2003 tentang Peninjauan Kembali Terhadap Materi dan Status Hukum Ketetapan MPR Tahun 1960 sampai 2002. ${ }^{14}$

\section{Pengujian Ketetapan MPR}

Majelis Pemusyawaratan Rakyat Republik Indonesia Nomor I/MPR 2003 tentang Peninjauan Terhadap Materi dan Status Hukum Ketetapan Majelis Pemusyawaratan dan Ketetapan Majelis Pemusyawaratan Rakyat 1960 sampai 2002 yaitu;

1. Pasal 1 ( 8 Ketetapan )

Tap MPRS/MPR sebagaimana dimaksud di bawah ini dicabut dan dinyatakan tidak berlaku

2. Pasal 2 (3 Ketetapan)

Ketetapan MPRS/MPR sebagaimana dimaksud di bawah ini dinyatakan tetap berlaku dengan ketetantuan masing-masing sebagai berikut.

3. Pasal 3 (8 Ketetapan)

Ketetapan MPRS/MPR ini tetap berlaku selama sampai dengan terbentuknya pemerintahan yang baru hasil pemilihan umum 2004.

${ }^{13}$ Dahlan Thaib, Ketatanegaraan Indonesia Persfektif Konstitusional, Penerbit Total Media, Yogyakarta, 2009, hlm. 242.

${ }^{14}$ Ibid., hlm 3. 
4. Pasal 4 (11 Ketetapan )

Ketetapan MPRS/MPR sebagaimana dimaksud di bawah ini tetap berlaku sampai dengan terbentuknya Undang-Undang.

5. Pasal 5 ( 5 Ketetapan )

Ketetapan MPRS/MPR sebagaimana dimaksud dinyatakan masih berlaku sampai dengan ditetapkan peraturan Tata Tertib yang baru oleh Majelis Pemusyawaratan Indonesia hasil Pemilihan Umum tahun 2004.

6. Pasal 6 (104 Ketetapan )

Ketatapan MPRS/MPR yang disebutkan di bawah ini merupakan ketetapan Majelis Pemusyawaratan Rakyat Republik Indonesia yang tidak perlu dilakukan tindakan hukum lebih lanjut, baik bersifat einmalig (final), telah dicabut, maupun telah selesai dilaksanakan. ${ }^{15}$

Kedudukan dan status hukum MPR kembali memperoleh angin segar setelah diundangkannya Undang-Undang No. 12 Tahun 2011 yang memberikan landasan hukum bagi keberlakuan kembali Ketetapan MPR dalam aturan hukum di Indonesia.

Berpijak dari penelusuran di atas, terlihat bahwa Tap MPR sebagaimana dimaksud pada Undang-Undang Nomor 12 Tahun 2011, Pasal 7 ayat (1) huruf b, hanya tersisa 6 Ketetapan masih berlaku hingga saat ini, yaitu;

\section{a. Pasal 2 Tap MPR Nomor I/MPR/2003}

1. Tap MPR XXV/MPRS/1966 tentang pembubaran Partai Komunis Indonesia, Pernyataan sebagai organisasi terlarang di seluruh wilayah Negara Republik Indonesia bagi Partai Komunis Indonesia dan larangan setiap kegiatan untuk menyebar atau mengembangkan Faham atau ajaran Komunis/Marxisme-Leninisme, Diberlakukan kedepan dengan keadilan dan menghormati Hukum, Prinsip Demokrasi dan Hak Asasi Manusia.

2. Tap MPR Nomor XVI/MPR/1998 Tentang Politik Ekonomi dalam Rangka Demokrasi Ekonomi, tetap diberakukan dengan ketentuan Pemerintah berkewajiban mendorong keberpihakan politik ekonomi, Usaha kecil menengah, dan koperasi sebagai pilar ekonomi dalam membangkitkan terlaksananya pembangunan nasional dalam rangka demokrasi ekonomi sesuai dengan Pasal 33 UUD NRI 1945.

b. Pasal 4 (11Ketetapan) Tap Nomor I/MPR/2003. Ketetapan MPR/S Republik Indonesia sebagaimana dimaksud di bawah ini tetap berlaku sampai dengan terbentuknya Undang-Undang.

1. Tap MPR Nomor XI/MPR/1998 tentang Penyelenggara yang Negara bersih dan Bebas Krupsi, Kolusi, dan Nepotisme tetap berlaku sampai terlaksananya seluruh ketentuan dalam keteapan tersebut. Sekerang telah terbentuk Undang-Undang tentang Pemberantasan Tindak Pidana Korupsi. Tetapi masih ada aspek yang terkait dengan Mantan Preisiden Soeharto yang belum terselesaikan hingga saat ini, sehingga ketetapan dinyatakan masih tetap berlaku.

2. Tap MPR Nomor VI/MPR/2001 tentang Etika Kehidupan Berbangsa,

15 Sekretariat Jenderal MPR RI, Ketetapan MPR Republik Indonesia No. I/MPR/2003 tentang Peninjauan Meteri dan Status Hukum Ketetapan MPR dari Tahun 1960 Sampai Tahun 2002, Cetakan Ke-14, M16.PR RI, Jakarta, 2014. 


\section{If Renaissance No. 1 VOL. 1 JANUARI 2016: 1 - 16}

3. Tap MPR Nomor VII/MPR/2001 Tentang Visi Indonesia Masa depan.

4. Tap MPR Nomor IX/MPR/2001 tentang Pembaharuan Agraria dan Pengelolaan Sumber Daya Alam, sampai terlaksananya seluruh ketentuan dalam Ketetapan tersebut.

Sebagaimana Putusan Mahkamah Konstitusi yang mengadili dan tidak menerima pengujian Tap MPR, hal ini akan berimplikasi terhadap Tap MPR yang masih berlaku dan tidak adanya kepastian hukum akan menimbulkan banyaknya tuntutan hak konstitusional yang dilanggar terhadap Tap MPR yang masih berlaku. Salah satu implikasi yang membuat penempatan Tap MPR dalam hierarki Undang-Undang Nomor 12 Tahun 2011 ini menjadi dilematis adalah potensi pertentangan Tap MPR dengan Undang Undang Dasar 1945 dan/atau Undang-Undang di bawahnya. Adapun beberapa yang muncul akibat pertentangan ini padahal Undang Undang Dasar Negara Republik Indonesia Tahun 1945 menjadi dasar berpijak dalam segala ketentuan perundang-undangan di Indonesia dan Mahkamah Konstitusi dibentuk sebagai solusi untuk lebih mewujudkan Indonesia sebagai negara hukum yang sesungguhnya, yaitu segala sesuatu bentuk pergaulan dalam hidup bermasyarakat berdasar atas hukum dan hukum dibentuk dengan berdasarkan pada aturan dasar filosofi bernegara, yaitu konstitusi. ${ }^{16}$

Terhadap Tap MPR yang berjumlah 6 ketetapan yang masih berlaku ini menimbulkan pertanyaan mengapa Tap MPR ini dimasukannya lagi kedalam UU No. 12 Tahun 2011 dalam Pasal 7 ayat (1) diatur tentang tata urutan (hierarki) peraturan perundang-undangan Republik Indonesia. Masuknya kembali Ketetapan MPR dalam hirarki merupakan sebuah politik hukum yang tidak lazim di tengah wacana perbaikan sistem hukum Indonesia. Terlebih Tap MPR diposisikan di atas Undang-undang dan di bawah Undang Undang Dasar 1945, yang sudah barang tentu merupakan sebuah posisi yang dilematis. Meski demikian, keberadaan Tap MPR menurut ketentuan hukum ini masih debatable. Hal ini mengingat berdasarkan Undang Undang Dasar NRI 1945 setelah amandemen kedudukan MPR tidak lagi sebagai lembaga tertinggi negara tetapi hanya sebatas lembaga tinggi negara sebagaimana lembaga-lembaga tinggi lain. Hal ini menimbulkan masalah hukum menyangkut kedudukan dan status hukum dari Ketetapan MPR yang masih berlaku di Indonesia karena masih memungkinkan adanya pertentangan dengan Undang-Undang di bawah dan termasuk dengan UUD NRI Tahun 1945.

${ }^{16}$ Dian Agung Wicaksono, "Implikasi Re-eksistensi Tap MPR dalam Hierarki Peraturan PerundangUndangan Terhadap Jaminan Atas Kepastian Hukum yang Adil di Indonesia", artikel dalam Jurnal Konstitusi, Vol. 10 No. 1, Maret 2013, hlm. 168. 
Dasar Pertimbangan Putusan Mahkamah Konstitusi

Menimbang bahwa pokok permohonan Pemohon adalah pengujian konstitusionalitas Pasal 6 angka 30 Ketetapan Majelis Permusyawaratan Rakyat Nomor I/MPR/2003 tentang Peninjauan terhadap Materi dan Status Hukum Ketetapan Majelis Permusyawaratan Rakyat Sementara dan Ketetapan Majelis Permusyawaratan Rakyat Republik Indonesia Tahun 1960 sampai dengan Tahun 2002 (selanjutnya disebut Tap MPR Nomor I/MPR/2003) dan Bab II Pasal Ketetapan Majelis Permusyawaratan Rakyat Sementara Nomor XXXIII/MPRS/1967 tentang Pencabutan Kekuasaan Pemerintah Negara dari Presiden Sukarno (selanjutnya disebut Tap MPRS Nomor XXXIII/MPRS/1967) terhadap Undang Undang Dasar Negara Republik Indonesia Tahun 1945 (selanjutnya disebut UUD 1945);

Menimbang bahwa sebelum mempertimbangkan pokok permohonan, Mahkamah Konstitusi (selanjutnya disebut Mahkamah) terlebih dahulu akan mempertimbangkan halhal sebagai berikut: a. kewenangan Mahkamah untuk mengadili permohonan a quo; $\mathrm{b}$. kedudukan hukum (legal standing) Pemohon untuk mengajukan permohonan a quo; Terhadap kedua hal tersebut, Mahkamah berpendapat sebagai berikut.

Bahwa berdasarkan Pasal 24C ayat (1) UUD 1945, Pasal 10 ayat (1) huruf a UU MK, dan Pasal 29 ayat (1) huruf a Undang-Undang Nomor 48 Tahun 2009 tentang Kekuasaan Kehakiman (Lembaran Negara Republik Indonesia Tahun 2009 Nomor 157, Tambahan Lembaran Negara Republik Indonesia Nomor 5076, selanjutnya disebut UU 48/2009), salah satu kewenangan konstitusional Mahkamah adalah mengadili pada tingkat pertama dan terakhir yang putusannya bersifat final untuk menguji UndangUndang terhadap Undang Undang Dasar;

Menimbang bahwa yang dimohonkan oleh Pemohon adalah pengujian konstitusionalitas Pasal 6 angka 30 Tap MPR Nomor I/MPR/2003 yang menyatakan:

"Ketetapan Majelis Permusyawaratan Rakyat Sementara dan Ketetapan Majelis Permusyawaratan Rakyat Republik Indonesia yang disebutkan di bawah ini merupakan Ketetapan Majelis Permusyawaratan Rakyat Sementara dan Ketetapan Majelis Permusyawaratan Rakyat Republik Indonesia yang tidak perlu dilakukan tindakan hukum lebih lanjut, baik karena bersifat einmalig (final), telah dicabut, maupun telah selesai dilaksanakan", yaitu, sepanjang frasa "Ketetapan Majelis Permusyawaratan Rakyat Sementara Republik Indonesia Nomor XXXIII/MPRS/1967 tentang Pencabutan Kekuasaan Pemerintahan Negara dan Presiden Soekarno" dan Bab II Pasal 6 Tap MPRS Nomor XXXIII/MPRS/1967 yang menyatakan, "Menetapkan penyelesaian persoalan hukum selanjutnya yang menyangkut Dr. Ir. Soekarno, dilakukan menurut ketentuan-ketentuan hukum dalam rangka menegakkan hukum dan keadilan, dan menyerahkan pelaksanaannya kepada Pejabat Presiden"; 
Bahwa menurut Mahkamah, permohonan a quo pernah diajukan sebelumnya dan diputus oleh Mahkamah dalam Putusan Nomor 24/PUU-XI/2013, bertanggal 10 September 2013. Dalam putusan tersebut, Mahkamah mempertimbangkan, "Mahkamah perlu mempertimbangkan kewenangan Mahkamah yang diatur secara limitatif dalam Pasal 24 C ayat (1) UUD 1945, yaitu "menguji Undang- Undang terhadap Undang Undang Dasar, memutus sengketa lembaga negara yang kewenangannya diberikan oleh Undang Undang Dasar, memutus pembubaran partai politik, dan memutus perselisihan tentang hasil pemilihan umum", dan Pasal 24C ayat (2) UUD 1945, yaitu "Mahkamah Konstitusi wajib memberikan putusan atas pendapat Dewan Perwaklian Rakyat mengenai dugaan pelanggaran oleh Presiden dan/atau Wakil Presiden menurut Undang- Undang Dasar". Selain itu, Mahkamah juga perlu mempertimbangkan eksistensi Ketetapan MPRS/MPR secara historis dalam beberapa peraturan yang mengatur tentang hierarki peraturan perundang-undangan, yaitu Ketetapan MPRS Nomor XX/MPRS/1966 tentang Memorandum DPR-GR Mengenai Sumber Tertib Hukum Republik Indonesia dan Tata Urutan Peraturan Perundangan Republik Indonesia (selanjutnya disebut Tap MPRS Nomor XX/MPRS/1966) dan Ketetapan MPR Nomor III/MPR/2000 tentang Sumber Hukum dan Tata Urutan Peraturan Perundang-undangan (selanjutnya disebut Tap MPR Nomor III/MPR/2000), serta Undang- Undang Nomor 12 Tahun 2011 tentang Pembentukan Peraturan Perundang-undangan (selanjutnya disebut UU 12/2011)" (vide Putusan Nomor 24/PUU-XI/2013, bertanggal 10 September 2013.

Pada bagian lain dalam putusan tersebut Mahkamah mempertimbangkan, "Menimbang bahwa berdasarkan Lampiran IIA Tap MPRS Nomor XX/MPRS/1966, Pasal 3 Tap MPR Nomor III/MPR/2000, serta Pasal 7 ayat (1) UU 12/2011, kedudukan Ketetapan MPRS/MPR ditetapkan secara hierarkis berada di bawah Undang Undang Dasar 1945 dan di atas Undang-Undang. Oleh karena Ketetapan MPRS/MPR mempunyai kedudukan yang secara hierarkis berada di atas UndangUndang maka berdasarkan Pasal 24C ayat (1) UUD 1945 pengujian terhadap Ketetapan MPRS/MPR tidak termasuk dalam kewenangan Mahkamah" (vide Putusan Nomor 24/PUU-XI/2013, bertanggal 10 September 2013, halaman 32.

Menimbang bahwa oleh karena permasalahan yang diuji dalam permohonan ini adalah sama dan telah dipertimbangkan dalam putusan tersebut di atas maka pertimbangan tersebut mutatis mutandis menjadi pertimbangan pula dalam putusan a quo, sehingga Mahkamah tidak berwenang mengadili permohonan a quo;

Menimbang bahwa oleh karena Mahkamah tidak berwenang mengadili permohonan Pemohon maka kedudukan hukum (legalstanding) Pemohon dan pokok permohonan tidak dipertimbangkan. Berdasarkan penilaian atas fakta dan hukum sebagaimana diuraikan di atas, Mahkamah berkesimpulan: Pertama, Mahkamah tidak berwenang untuk mengadili permohonan Pemohon a quo; kedua, Kedudukan hukum (legal standing) Pemohon dan pokok permohonan tidak dipertimbangkan. ${ }^{17}$

${ }_{17}$ Putusan Mahkamah Konstitusi No. 75/PUU-XII/2014, Jakarta, Tanggal 24 Juli 2014, hlm. 38. 


\section{Implikasi Pengujian Ketetapan MPR Pasca Putusan Mahkamah Konstitusi}

Putusan Mahkamah Konstitusi yang mengadili dan tidak menerima beberapa kali permohonan judicial review ke Mahkamah Konstitusi berdampak kepada keberadaan Ketetapan MPR di dalam hierarki peraturan perundang-undangan tidak ditemukan aturan atau mekanisme pengujian TAP MPR yang menyebabkan terjadinya kekosongan hukum serta tidak adanya lembaga yang berwenang untuk melakukan pengujian terhadap Ketetapan MPR, inilah yang dinamakan tetraa incognita. Sistem perundang-undangan merupakan subsistem hukum nasional yang mencakup semua hasil keputusan resmi yang tertulis dari penguasa yang mengikat umum, yang secara keseluruhan dalam kerangka sistem hukum nasional.

Ahli hukum tata negara yang juga mantan Ketua Mahkamah Konstitusi Jimly Asshiddiqie menganggap, Mahkamah berwenang menguji Ketetapan MR berdasarkan Ketetapan Nomor I/MPR/2003 Pasal 4 yang menyatakan (11) Ketetapan MPR dan MPR sebagaimana dimaksud di bawah ini tetap berlaku sampai dengan dibentuknya UndangUndang. Hal inilah yang mendasari Mahkamah Konstutusi berwenang, terbantahkan dengan putusan Mahkamah Konstitusi tersebut.

Menurut Hans Kelsen jika norma menetapkan bahwa perilaku tertentu "seharusnya" dilakukan, dalam arti "memerintahkan" perilaku itu, maka perilaku aktualnya boleh jadi sesuai atau tidak sesuai dengan norma tersebut. ${ }^{18}$ Sistem hukum akan memperoleh makna normatifnya hanya dari kaidah-kaidah lain yang lebih tinggi. Tata hukum merupakan suatu hirarki kaidah-kaidah (grundnorm). Grundnorm theory atau stufenbau theory, yaitu dalil yang menganggap bahwa semua hukum itu bersumber pada satu induk. Dalam pengertian ini, setiap norma hukum "yang lebih tinggi” adalah "sumber" dari norma hukum "yang lebih rendah". ${ }^{19}$

Demikian pula Scheltema menjelaskan, bahwa asas kepastian hukum dalam negara hukum bertujuan untuk menjamin bahwa kepastian hukum terwujud dalam masyarakat. Hukum bertujuan untuk mewujudkan kepastian dalam hubungan antar-manusia, yakni menjamin prediktabilitas dan juga bertujuan untuk mencegah bahwa hak terkuat yang berlaku. ${ }^{20}$

Merujuk pada Pasal 22 A Undang Undang Dasar 1945, mengamanatkan untuk membentuk undang-undang tentang tata cara pembentukan undang-undang. Dengan

${ }^{18}$ Ibid., hlm. 19-20.

${ }^{19}$ Op. Cit., hlm. 188-189.

20 B. Arief Sidharta, Kajian Kefilsafatan tentang Negara Hukum, Jentera: Jurnal Hukum, Pusat Studi Hukum dan Kebijakan Indonesia (PSHK). 2004, Edisi 3 Tahun II, hlm. 124. 


\section{Ifx Renaissance No. 1 VOL. 1 JANUARI 2016: 1 - 16}

pendekatan normatif tersebut maka mutatis mutandis kedudukan Ketetapan MPR di bawah UUD 1945 terderogasi dengan norma organik sebagaimana Pasal 22 A Undang Undang Dasar 1945, sehingga menjadi koherensi norma yang memungkinkan Ketetapan MPR akan menjabarkan materi Undang Undang Dasar 1945.

Merujuk Pasal 28 J ayat (2) Undang Undang Dasar 1945 bahwa konstitusi dapat membatasi Hak Asasi Manusia hanya dengan undang-undang dan bukan dengan produk hukum lain. Tetapi Ketetapan MPRS Nomor XXV/MPRS/1966 tentang Pembubaran Partai Komunis Indonesia (termasuk larangan paham komunis) jelas mengandung materi muatan yang jelas melakukan pembatasan Hak Asasi Manusia.

Masalah lainnnya yaitu tidak ada mekanisme pengujian terhadap Ketetapan MPR menyebabkan terjadinya kekosongan hukum serta tidak adanya lembaga yang berwenang untuk melakukan pengujian terhadap Ketetapan MPR, inilah yang dinamakan tetraa incognita.

Selain itu keberadaan Ketetapan MPR telah menjadikan tidak adanya kepastian hukum dan menciderai keadilan dan hak konstitusional warga negara sebagaimana amanat Pasal 28 D Undang Undang Dasar 1945, dengan begitu tanpa disadari telah menciderai konsepsi negara hukum dalam jaminan, pemenuhan dan perlindungan hak asasi manusia.

Sebagaimana telah di uraikan di atas, bahwa hierarki peraturan adalah murni bentuk pilihan kebijakan pembentuk undang-undang. Namun yang dipermasalahkan adalah bukan masalah salah atau benar penempatan Ketetapan MPR tersebut, namun yang menjadi permasalahannya adalah implikasi yang ditimbulkan dari Ketetapan MPR tersebut, jika berpotensi bertentangan dengan Undang Undang Dasar. Di sisi yang lain, DPR dan pemerintah tidak mengatur pengujian Ketetapan MPR tersebut. Di dalam Undang-Undang Nomor 12 Tahun 2011 Pasal 9 ayat (1) bila suatu Undang-Undang bertentangan dengan Undang Undang Dasar maka yang berwengan mengujinya adalah Mahkamah Konstitusi dan ayat (2) Jika Peraturan-Peraturan di bawah undang-undang bertentangan yang dapat mengujinya adalah Mahkamah Agung. ${ }^{21}$ Ketentuan konstitusional tersebut berarti bahwa sistem ketatanegaraan Indonesia berdasarkan Undang Undang Dasar 1945 harus berdasarkan atas prinsip kedaulatan rakyat dan prinsip negara hukum.

Undang-Undang Nomor 12 Tahun 2011 menegaskan bahwa untuk mewujudkan Indonesia sebagai negara hukum maka negara berkewajiban melaksanakan pembangunan hukum nasional dalam sistem hukum nasional yang menjamin perlindungan hak dan

${ }^{21}$ Lihat Pasal 9 ayat (1) dan ayat (2), UU Nomor 12 Tahun 2011 tentang Pembentukan Peraturan Perundang-undangan. 
kewajiban segenap rakyat Indonesia berdasarkan Undang Undang Dasar Negara Republik Indonesia Tahun 1945.

Ditempatkannya kembali Ketetapan MPRS dan Ketetapan MPR RI sebagai salah satu jenis perundang-undangan dalam hierarki perundang-undangan sebagaimana diatur dalam Undang-Undang Nomor 12 Tahun 2011 didasarkan pada pemikiran bahwa undangundang tentang Pembentukan Peraturan Perundang-Undangan merupakan pelaksanaan dari perintah Pasal 22 A Undang Undang Dasar Negara Republik Indonesia Tahun 1945 yang menyatakan bahwa "Ketentuan lebih lanjut mengenai tata cara pembentukan undangundang diatur lebih lanjut dengan undang-undang”. Namun, ruang lingkup materi muatan undang-undang ini diperluas tidak saja undang-undang tetapi mencakup pula peraturan perundang-undangan lainnya, selain Undang Undang Dasar Negara Republik Indonesia Tahun 1945 dan Ketetapan Majelis Pemusyawaratan Rakyat.

Harus diakui banyak mutiara pemikiran para negarawan kita pada masing-masing zamannya terdapat dalam Ketetapan MPR dan MPRS tersebut, yang tidak sepantasnya dibuang begitu saja dari aspek hukum tata negara juga tidak layak diturunkan menjadi undang-undang karena sebagian besar kaidah yang ada didalam Tap MPR berisi materi muatan Konstitusi atau UUD 1945. ${ }^{22}$

Penempatan Ketetapan MPRS/MPR setingkat di bawah UUD 1945 dalam tata urutan peraturan perundang-undangan membawa konsekuensi bahwa Ketetapan MPR harus selaras dengan UUD 1945. Dalam arti Ketetapan MPR tidak boleh bertentangan dengan ketentuan UUD NRI 1945, apabilah bertentangan maka Ketetapan MPRS dan MPR kehilangan keabsahannya. Dalam hal muatan materi MPRS dan MPR bertentangan dengan UUD NRI 1945, tentunya dapat ketetapan tersebut dapat di uji terhadap UUD 1945 (uji konstitusional). Sebaliknya, Ketetapan MPRS dan MPR menjadi sumber dasar bagi pembentukan peraturan perundang-undangan yang ada dibawahnya.

Untuk menjaga kesatuan sistem tata hukum dalam negara, maka perlu dilakukan pengujian apakah satu kaidah hukum tidak berlawanan dengan kaidah hukum lain, dan terutama apakah suatu kaidah hukum tidak ingkar dari atau bersifat menyisihkan kaidah hukum yang lebih penting dan lebih tinggi derajatnya. ${ }^{23}$

Kedudukan Tap MPRS dan MPR dengan konsekuensi yuridisnya tersebut, justru menjadi masalah karena ketidakjelasan dan inkonsistensi pengaturan dalam UU No. 12 Tahun 2011 itu sendiri. tidak adanya mekanisme pengujian Ketetapan MPRS dan MPR dan

${ }^{22}$ Dahlan Thaib, Ketatanegaraan ... Op. Cit., hlm. 241.

${ }^{23}$ Ni'matul Huda, Perkembangan Hukum Tata Negara Perdebatan \& Gagasan Penyempurnaan, Penerbit FH UII Press, Yogyakarta, 2014, hlm. 25. 


\section{Ifx Renaissance No. 1 VOL. 1 JANUARI 2016: 1 - 16}

hal ini menimbulkan kekosongan pengaturan. Sedangkan dalam Pasal 9 UU No. 12 Tahun 2011 terdapat pengaturan pengujian peraturan perundang-undangan, tetapi hanya sebatas undang-undang terhadap UUD 1945 yang dilakukan oleh Mahkamah Konstitusi dan peraturan perundang-undangan di bawah UU terhadap UU yang dilakukan oleh Mahkamah Agung.

\section{Penutup}

Mahkamah Konstitusi dalam sistem ketatanegaraan Indonesia tidak berwenanagn menguji Ketetapan MR. Adapun dasar hukum yang digunakan oleh Mahkamah Konstitusi mengadili dan tidak menerima pengujian Ketetapan MPR adalah berdasarkan Pasal 24C ayat (1) UUD 1945, Pasal 10 ayat (1) huruf a UU MK, dan Pasal 29 ayat (1) huruf a Undang-Undang Nomor 48 Tahun 2009 tentang Kekuasaan Kehakiman (Lembaran Negara Republik Indonesia Tahun 2009 Nomor 157, Tambahan Lembaran Negara Republik Indonesia Nomor 5076, selanjutnya disebut UU 48/2009), salah satu kewenangan konstitusional Mahkamah adalah mengadili pada tingkat pertama dan terakhir yang putusannya bersifat final untuk menguji undang-undang terhadap Undang Undang Dasar.

Implikasi yang ditimbulkan oleh Putusan Mahkamah Konstitusi yang mengadili dan tidak menerima permohonan judicial review adalah: berdampak kepada keberadaan Ketetapan MPR di dalam hierarki peraturan perundang-undangan tidak ditemukan aturan atau mekanisme pengujian TAP MPR yang menyebabkan terjadinya kekosongan hukum serta tidak adanya lembaga yang berwenang untuk melakukan pengujian terhadap Ketetapan MPR, inilah yang dinamakan tetraa incognita.

Selain itu keberadaan Ketetapan MPR telah menjadikan tidak adanya kepastian hukum dan menciderai keadilan dan hak konstitusional warga negara sebagaimana amanat Pasal 28 D Undang Undang Dasar 1945, dengan begitu tanpa disadari telah menciderai konsepsi negara hukum dalam jaminan, pemenuhan dan perlindungan hak asasi manusia.

\section{Daftar Pustaka}

A.H.S., Attamimi Peraturan Keputusan Presiden RI dalam Penyelenggaraan pemerintahan Negara Suatu Studi Analisis Mengenai Keputusan Presiden yang Berfungsi Pengaturan dalam Kurun Waktu Pelita i-iv (Disertasi) Fakultas Pasca Sarjana Universitas Indonesia. 1990. 
Agung, R. Laksono, "Dewan Perwakilan Rakyat Repoblik Indonesia Pasca Perubahan Undang Undang Dasar Negara Republik Indonesia tahun 1945", Artikel dalam Jurnal Majelis, Vol. 1 No. 1, 2009.

Agung Wicaksono, Dian, "Implikasi Re-eksistensi Ta MPR dalam Hierarki Peraturan Perundang-Undangan Terhada Jaminan Atas Kepastian Hukum yang Adil di Indonesia" Artikel dalam Jurnal Konstitusi, Vol. 10 No. 1, Maret 2013,

Asshiddiqie, Jimly, Perihal Undang-Undang, Raja Grafindo Persada, Jakarta, 2010. , Konstitusi dan Konstitusionalisme Indonesia, Konstitusi Press, Jakarta, 2005. Hukum Acara Pengujian Undang-Undang, konstitusi Press, Jakarta, 2006.

Attamimi, A. Hamid, Peranan Keputusan Presiden RI dalam Penyelenggaraan pemerintahan Negara Suatu Studi Analisis Mengenai Keputusan Presiden yang Berfungsi Pengaturan dalam Kurun Waktu Pelita i-iv (Disertasi) Fakultas Pasca Sarjana Universitas Indonesia, 1990.

Fatmawati, Hak Menguji (toetsingsrecht) Yang Dimiliki Hakim dalam Sistem Hukum Indonesia, Cet.2, P.T. Raja grafindo, Jakarta, 2006.

Hamidi, Jazim, Pembentukan Peraturan Perundang-Undangan, Tatanusa, Jakarta, 2005.

HR, Ridwan, Hukum Administrasi Neagara Edisi Revisi, RajaGrafindo Persada, Jakarta, 2010.

Huda, Ni'matul, Perkembangan Hukum Tata Negara Perdebatan \& Gagasan Penyempurnaan, Cet. 1, FH UII Press, Yogyakarta, 2014,

, Hukum Tata Negara Indonesia, Raja Grafindo Persada, Jakarta, 2009, , Perkembangan Hukum Tata Negara, FH UII Press, Yogyakarta, 2014.

Huijbers, Theo, Filsafat Hukum Dalam Lintas Sejarah, Kanisius, Yogyakarta, 1982.

H.R, Ridwan, Hukum Administrasi Negara, PT Raja Grafindo Persada, Jakarta, 2006.

Joachim, Carl, Friedrich Filsafat Hukum Perspektif Historis, Nuansa dan Nusamedia, Bandung, 2004.

Kelsen, Hans, teori Umum Tentang Hukum dan Negara Judul Aslinya (Theory Of Law and State) Diterjemahkan Rasul Muttakin, Nusa Media, Bandung, Cetakan ke IV, Tahun 2010, Jimly Asshiddiqic, Teori Hans Kelsen Tentang Hukum, Konstitusi Perss, Jakarta, 2009.

Magnar, Kuntana, "Kedudukan, Tuga, fungsi dan Kewenangan Lembaga-lembaga Negara Indonesia". Artikel dalam Jurnal Ilmu Hukum Litigasi, Vol 1. No. 2 Th. 2007.

Mahfud MD., Mohammad, Konstitusi dan Hukum dalam Kontroversi Isu, Raja Grafindo, Jakarta, 2010.

Nazriyah, Riri, MPR RI Kajian Terhadap Produk Hukum dan Prospek di Masa Depan, UII Press, Yogyakarta, 2007.

Pigome, Martha, "Implementasi Prinsip Demokrasi Nomokrasi Dalam Struktur Ketatanegaraan Pasca Amandemen UUD 1945" Artikel dalam Jurnal Dinamika Hukum, Vol. 113, 2000.

Salim, Hs dan Erlies Septiana Nurbani, Penerapan Teori Hukum Pada Tesis dan Dosertasi, Raja Grafindo Persada, Jakarta, 2013. 


\section{Ixx Renaissance No. 1 VOL. 1 JANUARI 2016: 1 - 16}

Simanjuntak, Marsilam, Pandangan Negara Integralistik, Temprint, Jakarta, 1994.

Sjarif, Amiroeddin, Perundang-undangan: Dasar, Jenis, dan Teknik membuatnya. Cet.2, rineka Cipta, Jakarta, 1997.

Soemantri, Sri, Prosedur dan Sistem Perubahan Konstitusi, P.T Alumni, Bandung, 2006.

Syafrudin, Ateng, Menuju Penyelenggaraan Pemerintahan Negara yang Bersih dan Bertanggung Jawab, Jurnal Pro Justisia Edisi IV, Universitas Parahyangan, Bandung, 2000.

Thaib, Dahlan, Ketatanegaraan Indonesia Persfektif Konstitusional, Total Media, Yogyakarta, 2009.

Triwulan Tutik, Titik “Analisis Kedudukan dan Status Hukum Ketetapan MPR RI berdasarkan Undang-Undang Nomor 12 Tahun 2011 Tentang Pembentukan Peraturan erundang-Undangan". Artikel dalam Jurnal Hukum Ius Quia Iustum, Vol. 20 No. 1, Januari 2013.

Mahkamah konstutusi Republik Indonesia Risalah sidang Perkara Nomor 86/PUU-XI/2013.

Jurnal Konstitusi, Vol. IV, No. 1, Juni 2011.

Jurnal Konstitusi, Volume. 10, No. 1, Maret 2013.

Jurnal Ius Quia Iustum, Volume. 20, No. 1, Januari 2013.

Jurnal Konstitusi, Volume.IV, No. 1, Juni 2011.

Dikutip dari artikel Hubungan antar Lembaga Negara, Indoskripsi.com, dikunjungi $15 / 12 / 2012$.

1http://www.hukumonline.com/berita/baca/lt522f2c5f42252/mk-tak-berwenang-ujitap-mpr

Undang Undang Dasar Negara Republik Indonesia tahun 1945

Ketetapan MPR RI No. I/MPR/2003 tentang Peninjauan kembali Tap MPR/S

Undang-Undang No. 12 Tahun 2011 tentang Pembentukan Peraturang PerundangUndangan

Republik Indonesia, Undang-Undang pembentukan Pertauran Perundang-Undangan, No. 12 Tahun 2011.

Lihat, UU Nomor 12 Tahun 2011 Pasal 1 ayat (1) huruf b.

Putusan Mahkamah Konstitusi Nomor 86/PUU-XI/2013.

Putusan Mahkamah Konstitusi Nomor 75/MPRS/2014.

Risalah Sidang Perkara Nomor 24/PUU-XI/2013.

Undang-Undang Nomor 12 Tahun 2011 tentang Pembentukan Peraturan PerundangUndangan (Lembaran Negara republik Indonesia Tahun 2011 Nomor 82, Lembaran Negara republik Indonesia Nomor 5324). 